W.P. 04-11

Structural reforms, macroeconomic policies and the future of Kazakhstan economy

Gilles Dufrenot, Alain Sand

Avril 2004

GATE Groupe d'Analyse et de Théorie Économique UMR 5824 du CNRS

93 chemin des Mouilles - 69130 Écully - France

B.P. 167 - 69131 Écully Cedex

Tél. +33 (0)4 72866060 - Fax +33 (0)4 72866090

Messagerie électronique gate@gate.cnrs.fr

Serveur Web : www.gate.cnrs.fr 


\title{
Structural reforms, macroeconomic policies and the future of Kazakhstan economy
}

\author{
Gilles DUFRENOT* \\ (ERUDITE, Université de Paris 12 and GREQAM, Marseille) \\ Alain SAND-ZANTMAN ${ }^{\dagger}$ \\ (GATE-CNRS, ENS-LSH, Université de Lyon 2 and OFCE, Paris)
}

April 28, 2004

\begin{abstract}
This paper presents a small macroeconomic model of Kazakhstan to study the impact of various economic policies. The simulations provide insight into the role of a tight monetary policy, higher foreign direct investment, rises in nominal wages and in crude oil prices. The results obtained are in line with the economic observations and give some support to the policies chosen as priority targets by the Kazakh authorities for the forthcoming years.
\end{abstract}

JEL classification: E17, F43, P47.

Keywords: Transition economies, Kazakhstan, Macroeconomic stabilization, Central Asian CIS countries

\section{Introduction}

During the decade of transition, a major challenge facing the CIS countries has been to adopt policies and reform strategies that foster economic growth and cut the strong inflation rates through a gradual change of their economies. How far they have been successful in pursuing such a goal is still a matter of debate. With respect to other former communist regions, like the Baltic or Central Europe, it seems that the CIS countries have performed middly ${ }^{1}$. However, two

\footnotetext{
* Corresponding Author. GREQAM-CNRS, Centre de la Vieille Charité, 2 rue de la Charité,13002, Marseille.Tél: +33.4.91.14.07.35.Email: lopaduf@aol.com.

†ENS-LSH, 15 Parvis René Descartes, BP 7000, 69342, Lyon, Cédex. Email:a.sand@enslsh.fr.

${ }^{1}$ For a comparison of economic performances during the ten first years of transition, see Havrylyshyn et al. (1998), Berg et al. (1999), Falcetti et al. (2000), Fischer and Sahay (2000), Wyplosz (2000).
} 
countries have performed reasonably well : Kazakhstan and Uzbekistan. The case of Uzbekistan is a puzzle since the countries has experimented high growth rates despite the fact that it was among the worst reformers of the CIS coun$\operatorname{tries}^{2}$. On the opposite, Kazakhstan is one of the countries in the region to have performed the most successful institutional reforms ${ }^{3}$ : modernization of the banking sector and of fiscal accounts, adoption of an inflation target policy, reduction of the external debt and of the debt service, increased productivity gains. Table 1 presents some key economic indicators for the Kazakh economy from 1994 to 2003. The successful transition is indicated by a strong growth recovery after the first years of the output decline, a sharp reduction of inflation from $1152 \%$ in 1994 to $6.8 \%$ in 2003 and the success of macroeconomic stabilization through an improvement of the internal and external balances. The aim of this paper is to propose a stylized macroeconomic model of Kazakhstan during the period of transition in order to analyze the consequences of a number of alternative economic policies that may explain the performances of the Kazakh economy. Until now, a limited number of macroeconometric models for this country exist. One explanation is probably the poor quality of the data available that are characterized by some bias (mainly due to measurement errors, weight of the informal sector and the short time span). Accordingly, we do not seek to obtain estimates from elaborate structural equations, but more modestly we shall try to give a broad overview of some macroeconomic trends governing the demand and supply sides of the economy. We use an empiricalbased approach by estimating error-correction equations. This means that we let the data determine the explanatory variables that play the most significant role among a list of potential variables the inclusion of which is initially dictated by the economic theory.

Regarding the economic policies, we study the impact of the following shocks.

Increase in the short-term interest rate. In the discussions on monetary policy for Central Asia countries during the transition, a usual prescription was that Central banks should adopt a credit restriction policy rather than increase the real interest rates. A first reason was the inefficient and underdeveloped banking sector with inexistent supervising activities. A second reason was that increases in interest rates may be resisted by fiscal authorities in a context where Central Banks are not independent. Though these arguments may be true for many CIS countries,they are likely not to apply to Kazakhstan. Indeed, the latter is one of the rare country of the region to have performed a successful modernization of its financial sector during the 1990's. Over the recent years, financial deepening has continued with a strong improvement of intermediation and banking supervision and a strong expansion of capital markets. Another important point is the following. As a consequence of the Russian crisis, Kazakhstan has adopted real exchange rate target in 1999 to avoid overvaluation of its currency that would be in contradiction with its inflation targeting policy maintaining high real interest rates. A real anchorage demands pursuing

\footnotetext{
${ }^{2}$ The Uzbek puzzle is discussed by Taube and Zettelmyer (1998) and Zettelmyer (1998).

${ }^{3}$ The issue of reforms in Kazakhstan is discussed in several recent papers (see, among others, Ramaurthy and Tandberg (2002), Bacalu (2003), Medas (2003)).
} 
macro-structural policies that are conducive to adequate internal and external balances. So, increased interest rate were likely not to be contradicted by the fiscal authorities' behavior. We simulate the effects of an increase of the short-term interest rate and show that the impact on the employment rate is not necessarily detrimental, depending upon the comparing effects on the real wages and productivity.

Higher amount of foreign direct investments. Transition is sometimes viewed as a catching-up phenomena to the technology level of developed countries. International technology transfers are usually proportionate to foreign direct investment (FDI). So, allowing a positive shock on the FDI is one way to envisage the effect of reducing the technological gap existing between Kazakhstan and its foreign partners. Foreign direct investment are highly concentrated, in terms of country origin (USA and Great Britain amount respectively for about 35\% and $15 \%$ and South Korea for more than $12 \%$ ) and sector of destination (more than $50 \%$ in oil and gas extraction). Our simulations show the positive impact of increased FDI, both on the demand side (multiplier effects) and supply side of the economy (productivity effects).

Increase in the real wages. There are opposite viewpoints concerning the question as whether it was a good prescription to reduce the wages in the CIS countries during the transition. On one hand, it can be argued that macroeconomic stabilization was directed at closing the gap between excessive aggregate demand and insufficient aggregate supply, a disequilibrium that typically characterized the Socialist economies. Restraining the wages was one of the measures suggested to achieve this goal. On the other hand, the view of excess demand economies as a characteristic of the former centrally planned economies is still questionable. Indeed, the existing discrepancies were naturally eliminated by high inflation and hyperinflation. This may explain why many CIS countries faced social resistance and were unable to successfully follow a wage reduction policy. In our model an increase in the real wages has a positive effect on the economic growth in the short-run. In the long-run, however, this implies stagflation and a higher unemployment.

Increase in the social expenditures.Human capital is at the core of economic growth. There are different measures depending upon the research field under consideration. From a labor theory perspective, a natural measure of Human capital is given by the earnings of an individual. In a growth context, human capital is cumulated through learning by doing and work experience. From a policy viewpoint, we can assume that the growth of expenditures in education results in a growth of income. Also, one can consider human capital as an externality of public investments such as healthcare and social transfers expenditures. In our model, an increase in the social expenditures positively affects the output growth. But this is a transitory effect. The positive impact is lowered by the long-run negative impact on employment and by price effects.

Increase in the world oil prices. The Kazakh growth depends on the oil industry in many respects. Firstly, capital inflows mainly concern the oil sector (half of the foreign direct investments). Secondly, the oil revenues are determinant for achieving both internal and external balances. Oil amounts for $25-30 \%$ of the 
budget resources and part of the inflows are saved to smooth the impact of oil prices volatility in international markets. Moreover, oil and gas amount to more than $50 \%$ of exports. Thirdly, the prices of oil and other extractive industries are correlated. Kazakhstan has a high endowment in other natural resources (minerals). Fourthly, productivity gains occurs through spillover effects from the oil sectors to non-oil sectors (in particular the sectors of construction and transportation). In regard to these different aspects, a variation in the oil price will have strong implications on the Economy. Our simulations show that the effect is mitigated. On one hand, higher oil prices induces positive multiplier effects which are beneficial for the global demand components. On the other hand, the wage-price loop yields a moderate positive impact on employment.

Higher international growth. We finally examine the contribution of the external anchor to the current growth of GDP. This factor is assumed to be the US GDP growth as a leading indicator of the world growth. The reform strategies adopted by Kazakhstan included trade liberalization. Today, the exports are oriented to Europe (22\%), Russia (14\%), China (10\%) and USA (4\%) and the imports come from Russia (45\%), Europe (23.5\%), USA (7\%) and China (5\%). An important question is whether the external anchor is conducive of growth. Our simulations show that, despite the reaction of the Central bank acting to reduce the inflationary pressure, higher external growth has a positive impact on both growth and the employment.

The paper is organized as follows. Section 2 contains the empirical estimation of the model. Section 3 presents the policy experiments. Finally, section 4 concludes the paper.

\section{Empirical estimation of the model}

The definitions of the variables are in table 2 All the variables are seasonally adjusted and come from the Kazakh national accounts (Ministry of Statistics). We use quarterly data over the period 1994:1 - 2001:4.

\section{Nonstationarity problems}

A first step is to test for the nonstationarity of the variables. The unit root tests, not reported here, showed mixed results. Some variables were $I(0)$, while others were $I(1)^{4}$. In this case, the application of the Engle-Granger's approach would yield misleading conclusions in terms of cointegration analysis. We thus prefer to use Pesaran, Shin and Smith (2001)'s methodology (henceforth referred as PSS (2001)). The authors propose a bound testing approach for the analysis of level relationships, when the regressors of a long-run equation are not purely $I(1)$.

To summarize, they suggest to use a conditional ECM regression of the

\footnotetext{
${ }^{4}$ The results are available upon request to authors.
} 
following type :

$$
\Delta y_{t}=c_{0}+c_{1} t+\pi_{y y} y_{t-1}+\pi_{y x} X_{t}+\sum_{i=1}^{p-1} \Psi_{i}^{\prime} \Delta Z_{t-i}+\omega^{\prime} \Delta X_{t}+u_{t}
$$

and to test the joint null hypotheses of the existence of a unit root in the endogenous variable, $y$, and the existence of a level relationship between this variable and its regressors (described by the vector $X$ ):

$$
H_{0}=H_{0}^{\pi_{y y}} \cap H_{0}^{\pi_{y x}}, \quad H_{0}^{\pi_{y y}}: \pi_{y y}=0^{\prime} \quad \text { and } \quad H_{0}^{\pi_{y x}}: \pi_{y x}=0^{\prime}
$$

against the alternative

$$
H_{1}=H_{0}^{\pi_{y y}} \cup H_{0}^{\pi_{y x}}, \quad H_{0}^{\pi_{y y}}: \pi_{y y} \neq 0^{\prime} \quad \text { or } \quad H_{0}^{\pi_{y x}}: \pi_{y x} \neq 0^{\prime}
$$

$Z$ is the vector $(y, X)$. This can be done by computing a Wald statistic. It can been shown that the critical values follow a non standard distribution. These values are tabulated in PSS (2001). Note that the way the intercept and the trend are incorporated in equation (1) refer to a general case. One can envisage different situations (no intercept and no trend, restricted intercept, restricted trend, etc).

To estimate the PSS ECM equations, we use an heteroscedastic- and autocorrelation consistent estimator. We also apply various misspecification tests to ensure that the residuals of the estimated models are white noise. We use a small open model describing the components of aggregate demand and aggregate supply.

\subsection{Aggregate demand}

A first set of equations describes the components of the aggregate demand: real consumption, investment rate, real imports, real exports, changes in inventories, and Government expenditures ${ }^{5}$.

- Real Consumption

$$
\begin{aligned}
\Delta \log \left(c_{t}\right)= & \underset{(1.387)}{1.924}-\underset{(-3.64)}{1.092} \log \left(c_{t-1}\right)+\underset{(2.24)}{0.765} \log \left(y_{t-1}\right)+\underset{(2.94)}{0.984 \Delta} \log \left(w_{t}(4)\right. \\
& -\underset{(-2.63)}{0.869 \Delta} \log \left(y_{t-1}\right)+\underset{(2.51)}{0.652 \Delta \log \left(c_{t-1}\right)} \\
\text { Wald }= & 7.51 \quad \text { crit }=[\underline{l}=4.94, \bar{l}=5.73]
\end{aligned}
$$

The real private consumption exhibits a significant long-run level relationship with real output. The result of the PSS test is read as follows. Because this test is based on a bound testing approach, we have a lower critical value, $\underline{l}$ and an upper critical value $\bar{l}$. These values depends upon the number of exogenous

\footnotetext{
${ }^{5}$ t-ratios are indicated in parentheses.
} 
variables used in the level (or long-run) relationships. Here, at $5 \%$ significance level, for $k=1$, we have $\underline{l}=4.94$ and $\bar{l}$. $=5.73$.(see PSS (2001)) The conclusion is as follows. If the computed Wald statistic lies below $\underline{l}$, then we accept the null hypothesis, which implies the rejection of a level relationship between the endogenous variable and its regressors. If instead the computed statistic lies above $\bar{l}$., we reject the null hypothesis and conclude in favor of the existence of a level relationship. If we find a computed statistic in the interval $[\underline{l}, \bar{l}$.$] ,$ then it is impossible to conclude. Here, the computed Wald statistics if higher than the upper critical value, which leads us to conclude in favor of a level relationship between the real consumption and its determinants. We see that the long-run real output elasticity is less than $1\left(\frac{0.765}{1.092}\right)$. The short-run real output coefficient can be expressed as $-0.869 \approx \frac{\Delta^{2} \log \left(c_{t}\right)}{\Delta^{2} \log \left(y_{t-1}\right)}$, so that the coefficient of $\Delta \log \left(y_{t-1}\right)$ captures the influence of the real output variability (or volatility) on real consumption. A higher volatility means more uncertainty about future growth and this encourages saving, thereby implying a decrease in the propensity to consume. We see that the sensitivity to output uncertainty is high. As expected, we have a high short-run propensity to consume the wages with an elasticity near 1.

- Investment rate

$$
\begin{aligned}
& \frac{I N V_{t}}{K_{t}}=\underset{(-1.55)}{-0.066}+\underset{(9.38)}{0.339} \frac{I N V_{t-2}}{K_{t-2}}+\underset{(4.83)}{0.042} \Delta \log \left(y_{t-1}\right) \underset{(-1.64)}{-0.008} \log \left(f d i_{t}(5)\right. \\
& \underset{(-7.48)}{-0.001 \Delta r_{t}}+\underset{(4.64)}{0.527 \text { gov }_{t}}+\text { DUMMY }(1995) \text {, } \\
& K_{t}=0.95 K_{t-1}+I N V_{t}, \quad \text { Wald }=40,13 \quad \text { crit }=[\underline{l}=3.79, \bar{l}=4.85]
\end{aligned}
$$

The main contribution of government expenditures to the investment rate is reflected by a high elasticity coefficient. Public investment is thus one of the cornerstones of a sustained capital growth. It is, however, important to note that the measurement of capital in CIS countries are subject to significant bias because the gross fixed capital formation comprises excessive capacities. Regarding the high coefficient, small reductions of public expenditures (for instance, through the modernization of old state firms) may imply a sharp decrease in the -inefficient- capital stock.

To construct the series of capital stock, we chose a depreciation rate such that the constructed series is compatible with the observed evolution of the gross fixed capital formation series. We also include a dummy variable in the regression, that accounts for the important fall of real investment during the year 1995. The choice of an appropriate depreciation rate is subject to debate in regard to the empirical implications. On one hand, given the important amount of inefficient capital, one could choose a high depreciation rate. But this choice is not compatible with the statistical properties of the investment series. Indeed, applying a unit root test, we found that the gross capital formation series was, at least $I(1)$, thereby indicating the presence of an important smooth component in the investment series. One is thus confronted to the problem of 
choosing a depreciation rate compatible with this statistical property. In this view, one can do the following remarks. Capital stock series are constructed by cumulating investment data. Choosing a high depreciation parameter would imply that the contribution of investment to capital disappears rapidly (if the assets included in the capital stock depreciate rapidly, then the contribution of the new flows of capital is small). The implications would imply that capital stock and investment do not evolve in phase. However, this contradicts several economic observations. In general, investment and capital stocks share similar downward or upward trends. Further, investment series are more volatile than capital stock series, thereby implying that the latter have more inertia than the former. As a consequence, if the investment variable is at least $I(1)$, the capital stock is expected to be at least $I(2)$. This is the case if one assumes a small depreciation rate in the capital stock equation, as above.

Foreign direct investment have a negative impact on the investment rate. This estimate indicate that FDI can help to measure the amount of inefficient capital during the transition, since resources are reallocated to productive activities. The consequence of resource reallocation is a transformational recession provoked by a decrease of the old non productive capital. Finally, we note the negative and significant impact of the real interest rate and the positive influence of the real output (as expected). The wald test yields to conclude that foreign direct investment and government expenditures are the two major determinants of the investment rate in the long-run.

- External trade : real exports and real imports

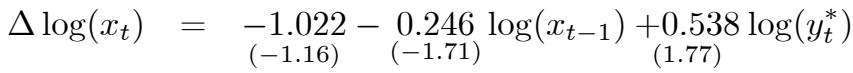

$$
\begin{aligned}
& +\underset{(2.09)}{0.369 \Delta B R E N T_{t}} \\
& \text { Wald }=1.669 \quad \text { crit }=[\underline{l}=4.94, \bar{l}=5.73] \\
& \Delta \log \left(m_{t}\right)=\underset{(-0.23)}{-0.006}+\underset{(3.00)}{0.557} \Delta \log \left(y_{t}\right)
\end{aligned}
$$

We choose the American GDP as a proxy of the world demand. We do this in regard to the efforts made by the Kazakh authorities to diversify trade, expand their international links and change the previous heavy dependence on Soviet trade routes for input supplies and exports. Foreign demand and oil prices are the crucial factors that explain real exports, while real imports heavily depends upon the domestic demand. The exogenous variables have only short-term effects, especially in the exports equation where the assumption of a long-run relationship is rejected. We did not succeed to find any role for competitiveness as a determinant of Kazakhstan's external balance (this variable was not significant in the regression). The reasons are the following. On exports markets, the country is price-taker because many of its exports comprise products, the price of which are determined by the international markets (gas, oil, grains, cotton, minerals, metals). This is also true for the imported products (petroleum products, electrical and mechanical equipments, vehicles). 
- Changes in inventories

$$
\Delta \text { stock }_{t}=\underset{(6.10)}{0.013}-\underset{(-3.68)}{0.32} \text { stock }_{t-1}-\underset{(-3.63)}{0.262} \Delta \log \left(x_{t}\right)
$$

Inventory stocks change in proportion to the exports growth. So, this equation captures the fact that inventories serves to meet changes in the demand of Kazakh products by the rest of the world. Note that, in terms of stockadjustment model, the estimation would imply a very small desired level of stocks $(0.013 / 0.32)$. A possible justification of such a behavior may be the structure of the Kazakh's external balance. It is known that energy and agricultural markets are volatile. So, the costs of stocking can become very high, especially during the periods of oversupply and falling prices. Note that this implies a smooth dynamics of the stocks (the previous period level accounts for $68 \%$ of the current level).

- Real Government expenditures

$$
\begin{aligned}
& \Delta G_{t}=\underset{(1.52)}{1.295}-\underset{(-2.22)}{0.55} \Delta \log \left(s_{t-2} B R E N T_{t-2}\right)-\underset{(-1.85)}{0.332} \log \left(G_{t-1}\right)(9) \\
& +\underset{(2.31)}{0.28} \log \left(s_{t-1} B R E N T_{t-1}\right) \\
& \text { Wald }=5.35 \quad \text { crit }=[\underline{l}=4.94, \bar{l}=5.73]
\end{aligned}
$$

This equation shows that the impact of changes in the oil price has a mixed effect on the Government expenditures. One effect is positive: higher oil prices imply increased resources in the Public finances allowing for higher expenditures. This is a "level" effect. A second effect is negative and related to the variability of the oil prices changes. More volatile prices increase the uncertainty on future budget resources. This renders future fiscal balances less credible and exposes the Government to capital outflows. To avoid this, the Government may decide to temporarily reduces its expenditures, signalling to the markets its willing to meet the budget targets. In Kazakhstan, such a behavior has been illustrated by the creation of a national fund to save part of the inflows to the budget from oil and extractive industries in order to smooth the impact of prices volatility.

\section{$2.2 \quad$ Labor market}

A second set of equations describes the labor market : employment, productivity and the industrial wages.

- Employment

$$
\begin{aligned}
\Delta \log \left(E_{t}\right)= & \left.\underset{(0.04)}{0.001}-\underset{(-3.36)}{0.010} \log \left(w_{t}\right)+\underset{(2.41)}{0.007} \log \left(y_{t}\right)-\underset{(-3.57)}{0.026} \log \left(E_{t-1}\right) 11\right) \\
& \quad-0.006 \Delta \log \left(w_{t}\right) \underset{(31.46)}{0.121} \Delta \log \left(y_{t}\right)-\underset{(-28.91)}{0.116 \Delta} \log \left(\text { PROD }_{t}\right) \\
\text { Wald }= & 5.56 \quad \text { crit }=[\underline{l}=3.79, \bar{l}=4.85]
\end{aligned}
$$


All the coefficients have the expected signs: the real wages and labor productivity have a negative impact on employment while the real output has a positive influence. Further, the four variables evolve in phase in the long-run, as indicated by the Wald test. In the short-run, the strongest influences are those of the real output and labor productivity. Although the official statistics do not give the distribution of employment among the different sectors, historically the employment growth is due to several factors. The first factor is the expansion of the service sectors favored by a policy encouraging private sector development. The second factor is the policy of import substitution which is viewed as a mean to accelerate industrialization. This resulted in increased Government investments in the manufacturing sector, which boosted the industrial output (the manufacturing sector accounts for half of the industrial production). The third factor is the authorities' diversification policy into labor-intensive sectors.

Productivity

$$
\Delta \log \left(P R O D_{t}\right)=\underset{(0.104)}{0.003}+\underset{(2.14)}{0.105 \Delta} \log \left(\text { depsoc }_{t-1}\right)+\underset{(2.01)}{0.377 \frac{I N V_{t}}{K_{t}}}
$$

Labor productivity varies positively with social expenditures (which include education, health care and social security spendings) and the rate of investment. Higher social spendings in Kazakhstan during the transition period were associated with the policy of economic diversification in order to reduce the economy's dependence on a few commodities (crude oil, natural gas and metals). Such spendings were viewed as a mean to increase labor productivity through a higher level of human capital, particularly in some sectors such as petroleum and petrochemical products. The latter are less affected by the swings of the world prices and have greater value added. The investment rate captures the productivity spillovers and externalities of foreign direct investment. In Kazakhstan, such spillovers have operated through two channels. Firstly, inflows of direct investment financed imports of tradable goods, such as equipments, that required a high level of human capital. Secondly, as indicated before, foreign direct investment induced resource reallocations from old inefficient activities to new productive sectors.

Industrial wages

$$
\begin{aligned}
\Delta \log \left(W_{t}\right)= & \underset{(-2.02)}{-0.386} \Delta \log \left(P_{t-1}^{c} / P_{t-1}\right)+\underset{(2.25)}{0.314 \Delta} \log \left(P_{t-1}^{c}\right)-\underset{(-4.95)}{1.272} \log \left(W_{t}(13)\right) \\
& -\underset{(-3.92)}{0.603} \log \left(P_{t-1}^{c} / P_{t-1}\right)+\underset{(4.94)}{1.363} \log \left(P_{t-1}^{c}\right)+\underset{(2.79)}{0.208} \log \left(P_{R O D} D_{t-1}\right) \\
\text { Wald }= & 8.58 \text { crit }=[\underline{l}=3.23, \bar{l}=4.35]
\end{aligned}
$$

The wage equation is representative of both the behavior of workers and firms. From the viewpoint of the workers, higher consumer prices yield revendication for an upward adjustment of the nominal wages. In the short-run, they ask for a partial adjustment (with an elasticity coefficient approximately equal to $1 / 3$ ). In the long-run, their revendication yields an overreaction of the nominal rate 
with an elasticity higher than 1.(that is 1.36/1.27). From the viewpoint of the firms, the ratio of the consumer prices over the producer prices determines their profit margins. An increase of profits necessarily means lower wages.

As expected, labor productivity has a positive influence on the wages. Finally, the Wald test yields to conclude in favor of a long-run relationships between the industrial wages and their determinants

\subsection{Prices}

A third set of equations indicates how prices are determined.

- Consumer prices

$$
\begin{aligned}
& \Delta \log \left(P_{t}^{c}\right)=\underset{(0.71)}{0.217}-\underset{(-5.37)}{0.238} \log \left(P_{t-1}^{c}\right)+\underset{(2.79)}{0.252 \Delta} \log \left(P_{t}\right)-\underset{(-1.63)}{0.140} \Delta \log (s(14) \\
& +\underset{(2.86)}{0.096 \log \left(s_{t-1}\right)}+\underset{(2.44)}{0.113} \log \left(y_{t-1}\right) \\
& \text { Wald }=18.97 \text { crit }=[\underline{l}=3.79, \bar{l}=4.85]
\end{aligned}
$$

- Producer prices

$$
\begin{aligned}
\Delta \log \left(P_{t}\right)= & \underset{(3.19)}{0.03}+\underset{(11.33)}{0.367} \Delta \log \left(P_{t-1}\right)+\underset{(3.65)}{0.181 \Delta} \log \left(B_{R E N T}\right) \\
& \underset{(-2.39)}{0.0013 t}+\underset{(2.35)}{0.041 D U M M Y(1999)}
\end{aligned}
$$

We assume that the consumer price is fixed by adding a mark-up to the marginal cost, the latter being proxied by the producer price. The coefficient of $P$ is, as expected, positive. Since the mark-up is a function of the elasticity of demand, it is usually empirically proxied by some variables representing the capacity utilization or the output-gap. Here, we use the real GDP. As expected, the latter has a positive influence on $P^{c}$. We further introduce a pass-trough effect. World prices influence the domestic prices through the nominal exchange rate variations. The impact of a depreciation $(\Delta s>0)$ depend on several factors: the degree of price controls, the degree of openness of the economy and the structure of external trade.. One expect a positive sign if, for instance, a depreciation yields an increase in the import prices and correlatively an increase of the domestic prices. We indeed obtain such a positive sign in our equation for the long-run coefficient, but the latter is very small (0.09/.023). Regarding the economic fact, this is not surprising at all. As shown by the short-run coefficient, the impact of exchange rate movements can even be negative (though the short-run coefficient is not statistically significant). Several factors were at work during the transition period, that prevent the positive pass-trough from foreign prices to domestic prices. Firstly, price controls continued to prevail on some non-tradable goods, which prevent switches in consumption from tradable 
to non-tradable goods. Secondly, the number of foreign producers relative to domestic producers has remained small

The specification for the producer prices includes the following elements. Changes in the prices of intermediate goods are captured by the price of oil. As is seen, the impact on the producer prices is positive and statistically significant. We further introduce a dummy variable for the year 1999, in order to capture the influence of the decrease of the prices in world commodity markets and the impact of the depreciation of the Ruble following the 1998's Russian crisis. Finally, we have a negative coefficient trend, illustrating the important contribution of the producer prices to the decreasing inflation rate during the transition period.

\subsection{Monetary policy}

The last equations reflect the monetary policy

- Interest rate

$$
\begin{aligned}
i_{t} & =\underset{(2.66)}{43.92}+\underset{(4.34)}{0.86} i_{t-1}-\underset{(-1.77)}{0.31} i_{t-2}+\underset{(2.12)}{79.99 \Delta} \log \left(P_{t}^{c}\right)-\underset{(-2.53)}{8.013} \log ((1 \mathrm{l} \bar{t}) \\
\text { Wald } & =6.42 \quad \text { crit }=[\underline{l}=4.94, \bar{l}=5.73]
\end{aligned}
$$

- Nominal exchange rate

$$
\Delta \log \left(s_{t}\right)=\underset{(2.47)}{0.018}+\underset{(4.28)}{0.385} \Delta \log \left(P_{t}\right) \underset{(-8.50)}{0.106} \operatorname{DU} M M Y(1995: 3)+\underset{(19.99)}{0.224} \operatorname{DU} M M Y(1999: 2)
$$

For the interest rate equation, we unsuccessfully tried to estimate a Taylor rule equation including different combinations of the following variables (the inflation rate, the output-gap, the money growth, unemployment,foreign interest rates). We finally consider an empirical interest rate rule that accounts for the Kazakh monetary authorities's main targets during the transition period. Their main intention has been to restrain inflation, to maintain the value of the National currency and to avoid the contagion effects of the financial crises occurring in other emerging countries (South-East Asia, Czech Republic, Russia). Theoretically, rising the interest rate helps to reduces the inflation rate, but this also implies capital inflows that induce an appreciation of the currency (or a decrease of $s_{t}$ ) in a floating exchange rate regime. In this case, an appreciation of the national currency is negatively correlated with higher interest rates. The authorities have decided to float the Tenge in April 1999, so the negative sign may apply for quarters after this date. But, even when the Tenge was pegged to the US Dollar (before 1999), it was hard to maintain the fixity of the nominal currency because the sterilization of capital inflows was very costly given the lack of liquidity of local security markets (given the initial situation of excess security's demand over security's supply, investors preferred to place their assets on international markets at lower interest rates. Keeping them at 
home supposed to propose very high interest rates which would have a depressing effect on the real activity). So, even before 1999 increased interest rates were concomitant with an appreciation of the Tenge. Note, however, that the appreciation has sometimes implied lowering the interest rates in order to avoid a Dutch disease.

We finally add a simple formulation of the purchasing power parity condition. The law of one price implies that any domestic price increase is compensated by a nominal depreciation. In the above equation, we have an expected positive sign for the coefficient of the variable $\Delta \log (P)$ We choose the producer price index because the PPP applies for goods that are internationally mobile. In the CIS countries, including Kazakhstan, tradable goods have a stronger influence on producer prices than on consumer prices. We also include two dummies. One corresponds to 1999:2, that is the date when the Tenge was de facto floating (before the official announcement in April). The second concerns the quarter 1995:2, corresponding to the beginning period of the pegging regime.

\section{$3 \quad$ Policy issues}

A wide body of research suggests that growth experience in transition economies, especially the CIS countries, depends upon the success or failure of the institutional and structural reforms (see, among many others, Falcetti, Raiser and Sanfey (2000), Havrylyshyn and Ron van Rooden (2000)). In this paper, we omit the institutional aspects of the reforms in Kazakhstan (due to the non availability of reliable data). More modestly, we study the effects of different adjustment scenarios, taking the estimations of the previous section as the main macroeconomic relationships governing Kazakhstan's economy during the transition period. Under the assumption that the estimated equations remain valid for the near future, the simulations used, though they apply to the years 1994:1 -2001:4, can give some flavor of the macroeconomic adjustment over the subsequent years.

\subsection{Choice of the policy scenarios}

We base our simulations on some policy scenarios that the Kazakh authorities found desirable to meet ten years after the beginning of the transition period. According to the authorities' economic program, as given in different international organizations' reports (IMF, World Bank, Asian Development Bank), several macroeconomic policies have been identified as priority targets (for the years 2002-2006), among which the following:

1. Achieve a target inflation rate of $4.5-5.5 \%$ and a GDP annual growth of $7-7.5 \%$.

2. Encourage further developments of the new capital in a context of limited domestic resource mobilization. This is necessary for the realization of the strategy on industrial development and innovations. 
3. Rise the wages of civil servants and employees of budget organizations

4. Develop the sectors of science and education to increase the workers' skill and improve the social welfare of population.

5. Take advantage of a better international environment.

Target 1. Among the policies required to bring the inflation down and/or stimulate the activity, two monetary instruments have been used by the Kazakh monetary authorities over the recent years. To stimulate growth, expansionary monetary policies are based on reduced refinancing rate and lower reserve requirements for commercial bank. Inflation can be bring under control by increasing the short-term interest rate. In Kazakhstan, the efficiency of an interest rate-based policy was eased by the modernization of the banking sector, the independence of the Central bank and by the fact that budgets deficits were kept under control. All these factors yield to an "interest-rate channel" that has been inexistent in many other CIS countries. How much emphasis must be placed on lowering inflation and on stimulating economic growth is subject to debate. In their intentions, the authorities seem to favor the control of inflation. In our simulation, we examine the impact of an increase in the short-term interest rate of 1 point.

Target 2. The building of a new capital is positively linked to international technology transfers. The latter act as a catching-up factor that contribute to the GDP growth. It is common wisdom that FDI's are conducive of technology transfers. Our purpose is to study the impact on the real activity of a $10 \%$ increase of foreign direct investments.

Target 3. In which direction, downward or upward, should wage adjustment take place in Kazakhstan? The conventional view of the international organizations is that increased wages have detrimental effects. If the wage increases concern the public sector, the consequence is an aggravation of the budget deficit and its negative impact on credibility, fiscal monetization and upward pressure of the interest rates. In the private sector, higher wages reduce the firms' competitiveness and induce rigidities in the labor market. In this case, a usual prescription is to restraint wages. Competing views concerning wage adjustment have, however, been put forward by some economists living in the CIS countries. Firstly, in a context of rapid growth, increasing the wages is a mean to ensure that the population reap the benefits of growth. This can be viewed as a redistributive policy. In particular, it may help to fight poverty (the authorities' goal is to reduce the share of population that has income below the line of poverty to 20\%). A second argument is based on efficiency wages: increased salaries are an incentive to higher the workers' labor productivity and seem essential to attract highly qualified labor. The potential inflationary pressures of higher wages should be limited by the concomitant increase of labor productivity. Taking the "optimistic" viewpoint, we simulate in our model the impact of a $1 \%$ increase of the nominal industrial wages.

Target 4. The Kazakh authorities are looking for ways to increase spendings in the social sectors because the country lacks qualified skills needed for the 
economic development. This is aggravated by the quotas imposed on skilled foreign workers. We study the impact of a $1 \%$ increase in the social expenditures

Target 5. In Kazakhstan, economic performance is highly influence by external factors, in particular changes in the prices of oil, natural gas, metals and by the business cycle phases of the trading partner countries. In our simulations, we envisage two favorable external shocks : an increase of $10 \$$ in the price of crude oil. and an international recovery leaded by a $10 \%$ increase in the US GDP.

\subsection{Results of the simulations}

The baseline scenario consists of the trajectories obtained for the different endogenous variables when the estimated model is solved ${ }^{6}$. The model comprises the behavioral equations plus the following national account identity linking aggregate output and its components. (the common deflator is the producer price index):

$$
\frac{Y_{t}}{P_{t}} \equiv \frac{C_{t}+S T O C K_{t}+I N V_{t}+E X P_{t}-I M P_{t}+G O V_{t}}{P_{t}}
$$

The real output is divided among the real consumption, the real inventory stocks, the real investment, the real net exports and the real government spendings.

The figures report the difference between the simulated trajectories after a given shock and the trajectories corresponding to the baseline scenario. So, a positive (resp. negative) value indicates an increase (resp. a decrease) of a variable in comparison to its values in the baseline scenario. All the shocks are permanent shocks occurring in 1997:1.

Permanent increase in the interest rate of 1 point

An increase in the interest rate shifts the rate of investment downward, inducing a negative multiplier effect, thereby causing the GDP components and the employment to decrease. The decrease in the output induces a lower consumer price level, which in turn implies a rise in the real wages. This rise causes the real consumption to be bid upward, which trigger a positive multiplier effect. The second effect is, however temporary, because it induces a rise in the consumer prices and thereby a decrease in the real wages. A tight monetary policy characterized by an increase in the interest rate thus helps to restraint inflation and has a detrimental effect on the output. However, the downward dynamics of the latter is attenuated by the positive real wage effect on the activity. This attenuation is more important, the less responsive to the interest rate is investment and the more responsive to real wages is real consumption.

A higher interest rate, by lowering the rate of investment, also induces a decrease in the labor productivity yielding an upward shift of the employment. In the context of our model, the negative response of labor productivity to a

\footnotetext{
${ }^{6}$ The model is solved with the nominal variables and then the endogenous variables expressed in real terms are deduced.
} 
decline in the rate of investment can be interpreted as the result of loss of productivity spillovers and positive externalities incorporated in the capital stock (this is in line with the interpretation of the productivity equation in the preceding section). To understand the consecutive increase in employment, the following remark is in order. Lower investment rate in transition economies is synonymous of modernization, which implies layoffs, in the short-run, as firms reduce their inefficient capital. This has two implications. The workers can change their skills and move to activities with more value added. They can choose to work in activities that are more labor intensive, which implies that they accept lower real wages. Kazakhstan's situation seems more in line with the second explanation. The country lacks highly qualified workers and further the authorities have been looking for way of diversification into labor intensive sectors.

An exogenous increase in the interest rate thus generates a positive priceoutput and price-employment correlation over the business cycle but a negative price-employment correlation over the long-run (prices diminish while employment increase). This comes from the fact that, in our model, employment responds to both aggregate demand (positively) and productivity (negatively).

Two conclusions can drawn from these observations. Firstly, attempt to disinflate by means of a tight monetary policy without depressing the activity too much is possible. To obtain a slowdown of the output decline, it is prudent to keep the nominal wages unchanged during the period of restricted monetary policy. Secondly, a restrictive monetary policy is likely not to result in a deepened depression with a high level of unemployment, if the labor productivity decrease inherent to restructurations is compensated by the development of labor intensive activities. But the latter entails a virtuous circle on employment, provided that workers accept a decrease in real wages.

\section{$10 \%$ permanent increase in foreign direct investments}

As is seen in figure 2, a higher amount of foreign direct investments induces a fall in output and its components. They indeed yield a decrease in the investment rate, creating a negative multiplier effects causing employment and the different component of the GDP to fall : real consumption, stocks of inventories, imports. In response to the output decline, consumer prices and the interest rate decrease. Lower consumer prices momentary yield a rise in the real wages. Since the latter are beneficial only to those workers who are still employed, the effect on the real consumption remains limited. By causing both the output and the employment to decrease, the FDI's also affect labor productivity. Since the output decreases faster than employment, labor productivity declines. This shifts the nominal wages downward and implies in turn a decrease in the real wages, thus tending to increase employment.

As a whole, higher FDI's can be viewed as a restructuring factor helping to close the gap between the excessive aggregate demand and the aggregate supply. The decline of the output and its components may thus be interpreted as an adjustment process.

$1 \%$ permanent increase in the industrial wages 
A rise in the wages causes an increase in real consumption which stimulates the activity through a positive multiplier effect. Employment thus increases. However, as observed in figure 3, this positive impact on the real variables is very transitory. Indeed, the rise in the output triggers an upward move of the consumer prices and the interest rate is bid downward by the Central bank to restraint inflation. This restrictive monetary policy causes the aggregate demand components to move back to their initial level.

As the monetary authorities attempts to control the inflation by rising the interest rate, the investment rate starts to decreasing, causing labor productivity to fall. Normally, this should result in an increase of employment. But, as the nominal wage increase is permanent, this results in higher labor costs that yields a fall of the employment.

The total effect of a rise in nominal wages is thus stagflation. Higher wages are accordingly neutral in the long-run as they leave all real variables unaltered. It is interesting to ask about the factors that could help to go beyond the neutrality. The answer is certainly that a policy aiming at rising the nominal wages should be combined with the adoption of measures implying higher labor productivity

\section{$1 \%$ permanent increase in social expenditures (in \% of the GDP)}

A rise in social expenditures means higher public spendings, which induces a positive multiplier effect causing the GDP components to increase. However, this positive effect is transitory, as observed in figure 4 . Indeed, higher output yields a rise in the consumer price index and this yields the Central bank to react by shifting the interest rate up.

The increase in social expenditures also rise the labor productivity, which in turn implies higher real wages. Since the latter increase at a more moderate rate than the productivity, employment thus decreases.

The long-run effect is thus an increase in the labor productivity. For this reason, higher social expenditures are usually assimilated to capital account expenditures, for they are spendings that yield to the accumulation of human capital that yield a higher rate of return of the economy. In Kazakhstan, such spendings are required for the development of specific sectors, in particular the oil and gas, telecommunication and construction sectors. A great deal hinges on the question of how to lower the negative impact on employment. An indicated policy may be to promote the diversification of the economy into labor intensive activities that highly contribute to economic growth. For instance, it may be interesting to expand the services sector, rather than the manufacturing and mining sectors, since the former has a great contribution to growth while the latter have little impact.

\section{$10 \%$ permanent increase in the US GDP}

The reforms undertaken by Kazakhstan during the transition period implied lower trade barriers and a higher diversification of the external trade. In analyzing the contribution of aggregate demand to growth, it is important to acknowledge that the country's growth rate has been importantly influenced by 
the world business cycle (this is a major difference with other CIS countries whose growth has continued to depend upon the Russian growth). Here, we study the impact of a world expansion leaded by a strong recovery in the USA.

The implications are those expected. As observed in figure 5, the result is a jump in the exports, causing the output components to adjust upward through a positive multiplier effect. This creates a rise in the consumer prices inducing lower real wage.. If the central Bank reacts by rising the interest rate, among the different components of the aggregate demand, investment is the only variable durably -negatively- affected. Lower investments bring labor productivity down and this raises employment.

As a whole, the simulations shows features that happens in export-oriented growth countries. The positive impact of the foreign growth compensates the negative effects of a restrictive monetary policy.

Permanent increase in the crude oil price of $10 \$$

An exogenous shock on the oil price boosts the exports (usually rises in energy prices are correlated with a positive turnaround of the world demand) and drives the producer prices upward (because oil products enter as intermediate goods in the domestic products). This triggers an increase in the consumer price and in the Central bank's interest rate. The law of one price in international markets implies a depreciation of the nominal exchange rate.

As is seen in figure 6, the nominal wages firstly increases sharply (in response to the increase of the consumer prices) but then rise more moderately. The reason is that the prices of non-tradable goods (CPI) rise at a slower rate than those of the tradable goods (PPI).

The combination of higher exports and increased wages has a positive effect on real consumption and the other components of the GDP (except the stock of inventories that globally diminish). The positive multiplier effect explains why the employment rise (they firstly rise sharply and then more moderately because the real wages and productivity have increased). Notice that the multiplier effect is reinforced by the fact that increased oil prices imply higher resources for the Government and thus higher public spendings.

Finally, it can be noticed that the monetary authorities modify their behavior over time. We see that the interest rate are first raised and then lowered. The explanation the nominal interest rate enter as a target in the Central Bank's reaction function (see the interest rate equation). The depreciation of the nominal exchange rate improve the external competitiveness, which is favorable for both external and internal balances. This reduces the inflationary pressures and allow to pursue an accommodative monetary policy.

\subsection{Concluding remarks}

This paper aimed at providing a stylized representation of the Kazakh economy over the period of transition in order to simulate the consequences of several economic policies viewed by the authorities as essential. The results we obtain 
are in line with the economic observations. The proposed model, however, suffers from some limitations that need to be mentioned. Firstly, policy reforms are accompanied by institutional transformations that imply changes of the economic structure. So, we cannot absolutely take for granted that the simulations done here should characterize Kazakhstan for the future years. However, this criticism yields us to formulate the following remarks. Until the transition is achieved,structural changes will occur. This means that any model describing the current situation of the CIS countries cannot be extrapolated into the future. A more serious argument is the following. The main problem posed by structural changes in macroeconomic models refers to the so-called Lucas-critique: the policies may be non operant if they induce reactions from the agents. Our model contains no assumptions concerning the domestic agent's expectations. In Kazakhstan and other CIS countries, the agents that react to the policy decisions are international organizations (IMF, World Bank, Bank for Development and Reconstruction, ...). Private investors, before taking a decision, refer to these organizations' viewpoint concerning the economic situation of the countries. But unlike what is observed in the case of domestic agents, the international organizations cannot directly nihil the impacts of a given policy. What they do is to provide a general operating framework to implement the policies.

The model suffers from a second limitation which is that it analyzes aggregate effects that hinder disaggregated effects. For instance, interesting questions are: how the above shocks are distributed across the different sectors? Do the impacts result from small or medium size firms? The answer to such question would require data that are not available. So, the macroeconomic approach is a stopgap.

This paper also opens perspectives for a future research agenda. In particular, it would be interesting to compare the Kazakhstan case with those of other CIS countries to see whether there are common factors underlying their economies growth, just as was the case for Central and Eastern Europe countries. Such a study could serve as a basis for recommendations coordinated policies in the Region of Central Asia.

\section{References}

[1] Bacalu, V., 2003, "Financial sector development", in Republic of Kazakhstan: selected issues and Statistical appendix, International Monetary Fund Country Report $n^{\circ} 03 / 211$.

[2] Berg, A., Borensztein, E., Sahay, R. and J. Zettelmyer, 1999, "The evolution of output in transition economies: explaining the differences", International Monetary Fund Working Paper n9973.

[3] Falcetti, E., Raiser, M. and P. Sanfey, 2000, "Defying the odds:initial conditions, reforms and growth in the first decade of transition", London School of Economics Working Paper, May. 
[4] Fischer, S. and R. Sahay, 2000, "The transition economies after ten years", National Bureau of Economic Research Working Paper $n^{\circ} 7664$.

[5] Havrylyshyn, O., Izvorski, I. and R. van Rooden, 1998, "Recovery and Growth in transition economies 1990-98: a stylized regression analysis", International Monetary Fund Working Paper n $98 / 141$.

[6] Medas, P., 2003, "The non-oil sector in Kazakhstan: links with the oil industry and contribution to growth, in in Republic of Kazakhstan: selected issues and Statistical appendix, International Monetary Fund Country Report $\mathrm{n}^{\circ} 03 / 211$.

[7] Pesaran, M.H., Shin, Y. and R.J. Smith, 2001, "Bounds testing approaches to the analysis of level relationships", Journal of Applied Econometrics 16, 289-326.

[8] Ramamurthy, S. and E. Tandberg, 2002, "Treasury reform in Kazakhstan: lessons for other countries", International Monetary Fund Working Paper, $\mathrm{n}^{\circ} 02 / 129$.

[9] Taube, G. and J. Zettelmyer, 1998, "Output decline and recovery in Uzbekistan: past performances and future prospects, International Monetary Fund Working Paper, $n^{\circ}$ 98/132.

[10] Wyplosz, C., 2000, "The ten years of transformation: macroeconomic lessons", CEPR discussion Paper, $\mathrm{n}^{\circ} 2254$.

[11] Zettelmyer, J., 1998, "The Uzbek growth puzzle", International Monetary Fund Working paper, $n^{\circ} 98 / 133$. 
Table 1: Internal and external indicators growth rates - Source : EIU, CDC IXIS, IMF, World Bank

\begin{tabular}{|c|c|c|c|c|c|c|c|c|c|c|}
\hline & 1994 & 1995 & 1996 & 1997 & 1998 & 1999 & 2000 & 2001 & 2002 & 2003 \\
\hline GDP growth $(\%)$ & $-12,7$ & -8.2 & 0.5 & 1.7 & -1.9 & 2.7 & 9.8 & 13.2 & 9.5 & 7.24 \\
\hline $\begin{array}{l}\text { Gross capital } \\
\text { formation }\end{array}$ & -13.0 & -36.6 & -24.7 & 3.6 & 1.7 & -0.5 & 23.6 & 30.0 & 12.0 & 15.0 \\
\hline $\begin{array}{c}\text { Private } \\
\text { consumption }\end{array}$ & -13.7 & -15.1 & 9.6 & 3.7 & -10.9 & -19.2 & 1.2 & 8.0 & 5.5 & 5.0 \\
\hline Exports & 2.1 & -4.0 & 20.1 & 14.9 & 10.1 & 18.7 & 23.9 & 16.0 & 13.0 & 11.0 \\
\hline Imports & 14.9 & -30.4 & 18.4 & 19.0 & -2.5 & -1.5 & 10.9 & 23.0 & 13.0 & 15.0 \\
\hline $\begin{array}{l}\text { Current account } \\
(\% \mathrm{GDP})\end{array}$ & -6.8 & -1.2 & -3.7 & -3.8 & -5.5 & -1.01 & 3.69 & -5.54 & -2.44 & -1.49 \\
\hline $\begin{array}{l}\text { External debt } \\
\text { (\% GDP })\end{array}$ & NA & NA & NA & 24.7 & 22.1 & 26.9 & 36.5 & 31.4 & 36.7 & NA \\
\hline Inflation rate & 1152.5 & 60.8 & 28.7 & 11.3 & 1.9 & 8.42 & 13.4 & 8.4 & 6.0 & 6.8 \\
\hline $\begin{array}{c}\text { Unemployment } \\
\text { rate }(\%)\end{array}$ & 7.8 & 12.0 & 9.4 & 8.1 & 6.8 & 13.5 & 12.8 & 10.4 & 9.3 & 8.8 \\
\hline $\begin{array}{c}\text { FDI } \\
(\text { Billions } \$)\end{array}$ & 0.6 & 1.0 & 1.1 & 1.3 & 1.3 & 1.6 & 1.3 & 3.0 & 2.1 & NA \\
\hline Exchange rate & 60.95 & 67.3 & 75.5 & 88.3 & 119.6 & 138.3 & 144.5 & 150.9 & 155.9 & 149.6 \\
\hline $\begin{array}{c}\text { Fiscal deficit } \\
(\% \mathrm{GDP})\end{array}$ & -4.3 & -9.1 & -4.4 & -4.0 & -3.5 & -0.1 & -2.1 & -0.4 & 0.3 & NA \\
\hline
\end{tabular}


Table 2: Variable names

\begin{tabular}{|c|c|c|c|}
\hline Variable & Name & Variable & Name \\
\hline$C$ & Private consumption & $y \equiv Y / P P I$ & Real GDP \\
\hline$c \equiv C / P$ & Real consumption & $F D I$ & $\begin{array}{l}\text { Foreign direct } \\
\text { investment }\end{array}$ \\
\hline$P$ & Producer price index & $f d i \equiv(F D I / G D P)$ & $F D I(\% G D P)$ \\
\hline$i$ & $\begin{array}{l}\text { Nominal short-term } \\
\text { interest rate }\end{array}$ & 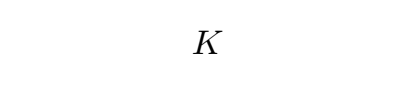 & Capital stock \\
\hline$r \equiv i-\Delta P^{c}$ & Real interest rate. & $E X P$ & Exports \\
\hline$Y$ & $\begin{array}{l}\text { Gross domestic } \\
\text { product }\end{array}$ & $x \equiv E X P / P P I$ & Real exports \\
\hline$P^{c}$ & $\begin{array}{l}\text { Consumer price } \\
\text { index }\end{array}$ & $I M P$ & Imports \\
\hline$W$ & $\begin{array}{c}\text { Nominal industrial } \\
\text { wages }\end{array}$ & $m$ & Real imports \\
\hline$w \equiv W / P^{c}$ & Real wages & $y^{*}$ & USA $G D P$ \\
\hline$I N V$ & $\begin{array}{c}\text { Gross fixed } \\
\text { capital formation }\end{array}$ & $B R E N T$ & Oil price \\
\hline$I \equiv I N V / P$ & Real investment & $s$ & $\begin{array}{l}\text { Nominal exchange } \\
\text { rate vs US } \$\end{array}$ \\
\hline$G O V$ & $\begin{array}{l}\text { Government } \\
\text { expenditures }\end{array}$ & $P R O D=Y / L$ & Labor productivity \\
\hline$S T O C K$ & $\begin{array}{l}\text { Inventories } \\
\text { Stocks }\end{array}$ & $E$ & Employment \\
\hline$L$ & Labor force & $S O C$ & Social expenditures \\
\hline$g o v \equiv G O V / G D P$ & $\begin{array}{l}\text { Gov. expenditures } \\
(\% \text { GDP })\end{array}$ & stock $\equiv S T O C K / G D P$ & $\begin{array}{l}\text { Stock of inventories } \\
\qquad(\% \mathrm{GDP})\end{array}$ \\
\hline$G \equiv G O V / P P I$ & $\begin{array}{c}\text { Gov. expenditures } \\
\text { (real) }\end{array}$ & depsoc $\equiv D E P S O C / P P I$ & $\begin{array}{c}\text { Social expenditures } \\
\text { (real) }\end{array}$ \\
\hline
\end{tabular}




\section{Figure 1}

A 1 Point Permanent Increase in the Interest Rate.

Real consumption

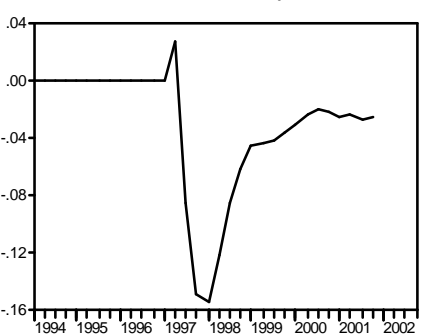

Real Exports

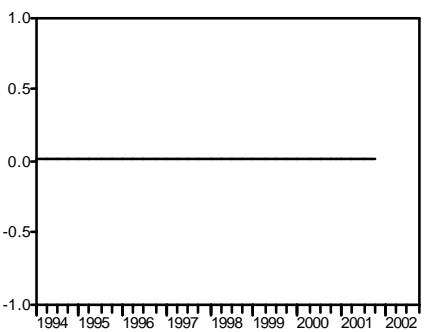

Real Investment

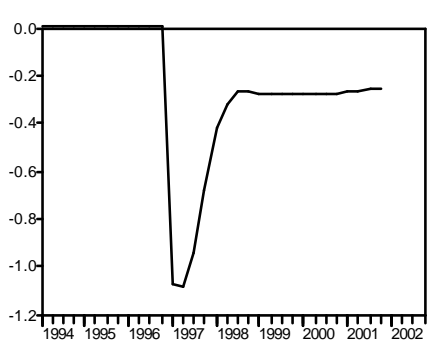

Changes in Inventories

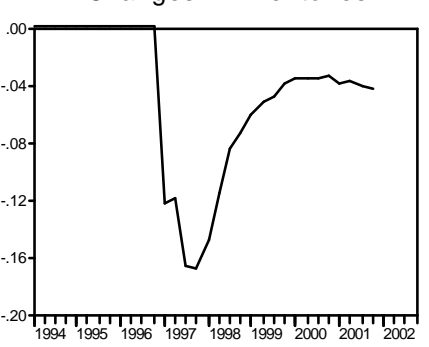

\section{Percent Deviation}
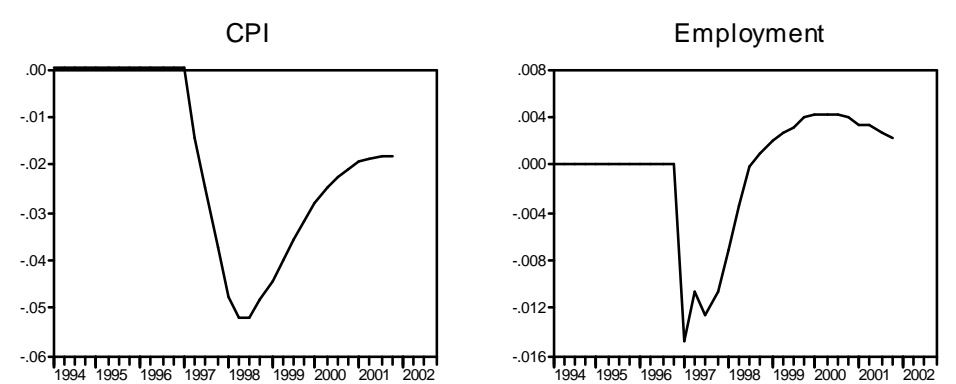

Nominal Exchange Rate

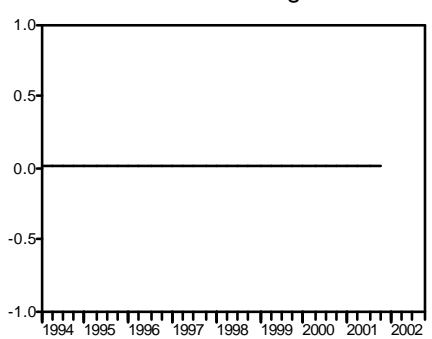

Real Government Expenditures

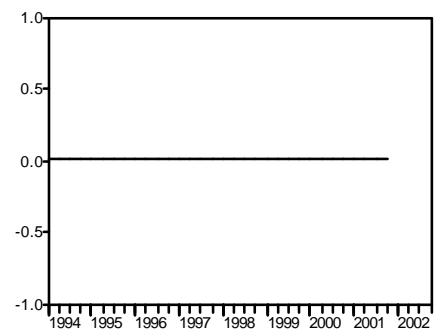

Real GDP

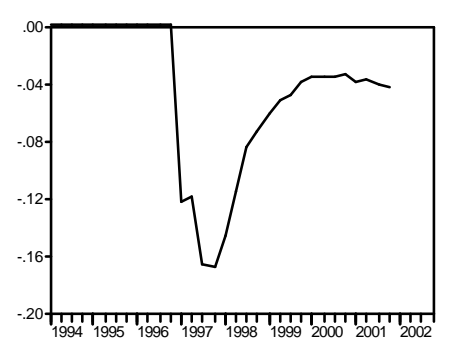

Real Imports

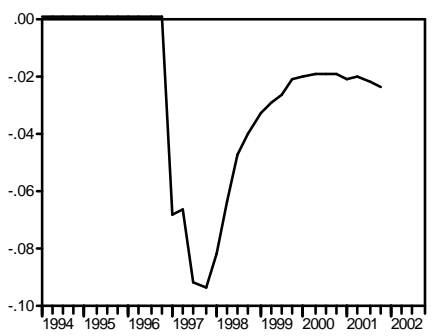

Productivity
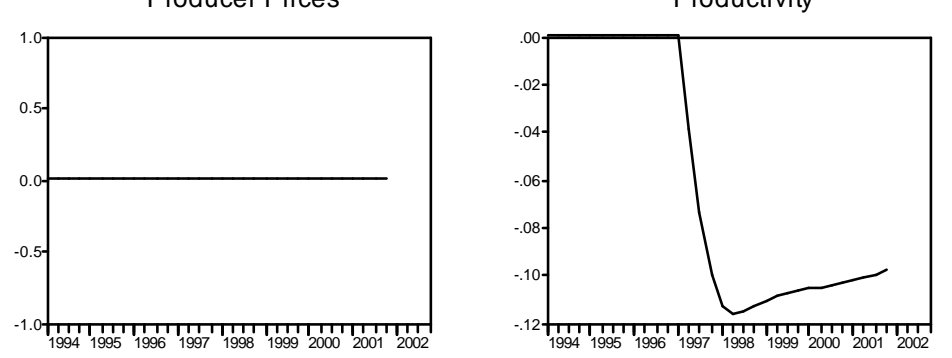

Real Interest Rate

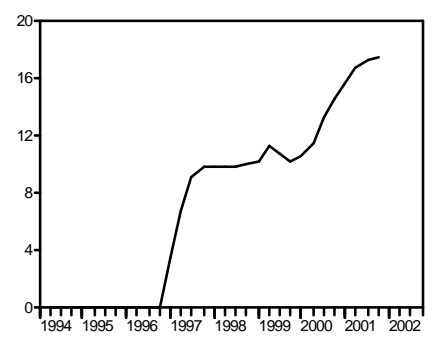

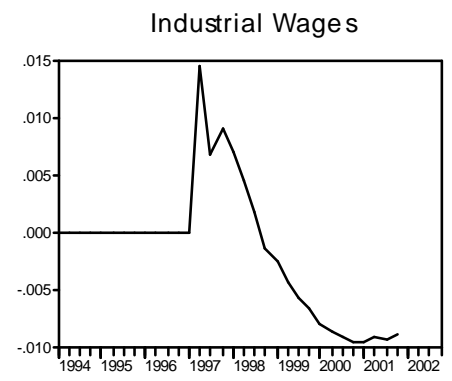




\section{Figure 2}

\section{A 10\% Permanent Increase in Foreign Direct Investments}

\section{Percent Deviation}

Real consumption

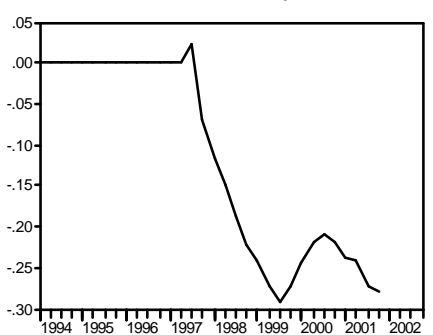

Real Exports

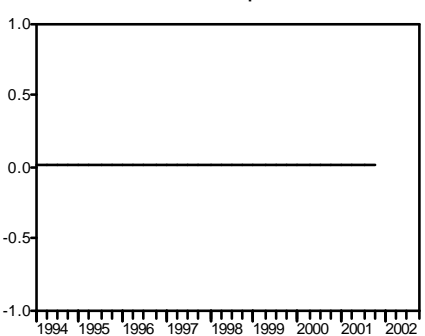

Real Investment

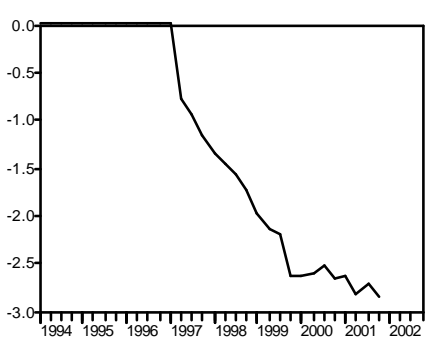

Changes in Inventories

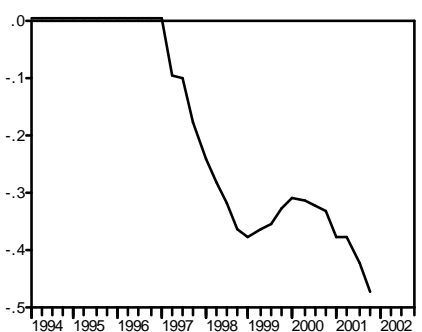

$\mathrm{CPI}$

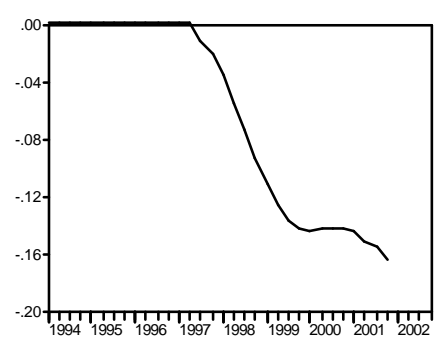

Real Government Expenditures

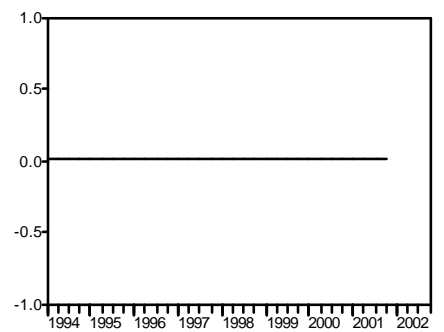

Producer Prices

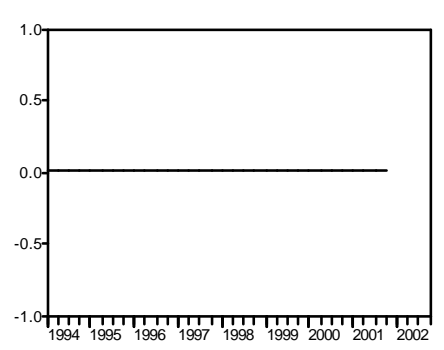

Industrial Wages

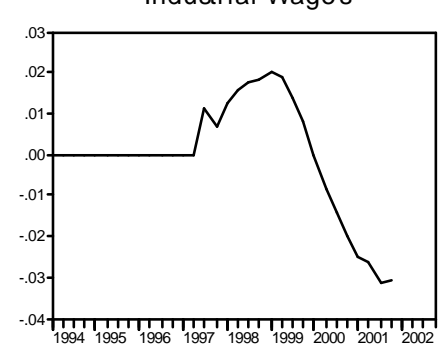

Nominal Exchange Rate

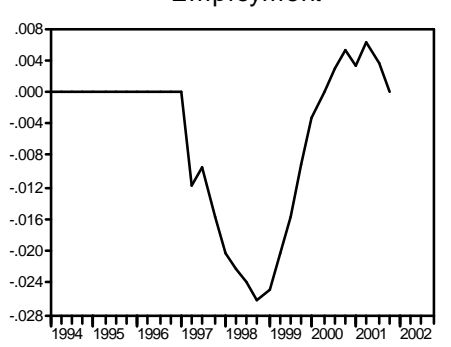

Real GDP

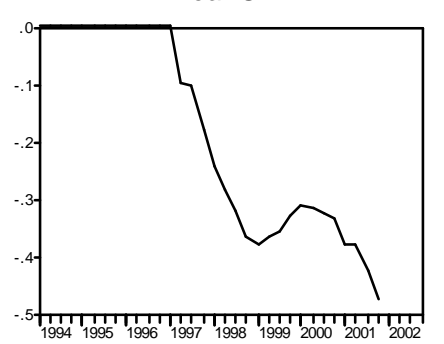

Productivity

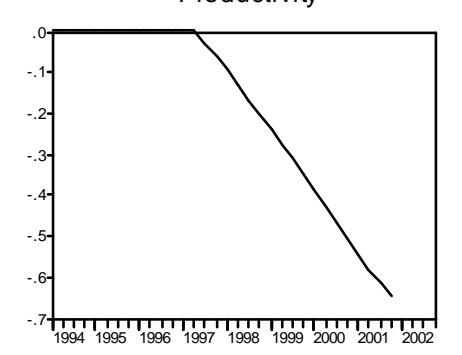

Real Interest Rate

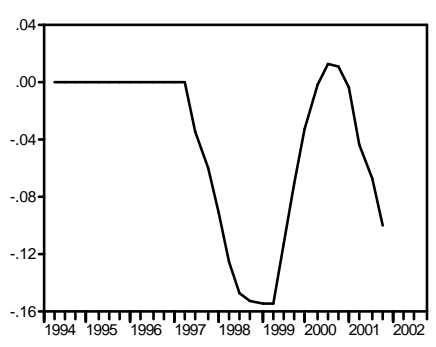

Real Imports

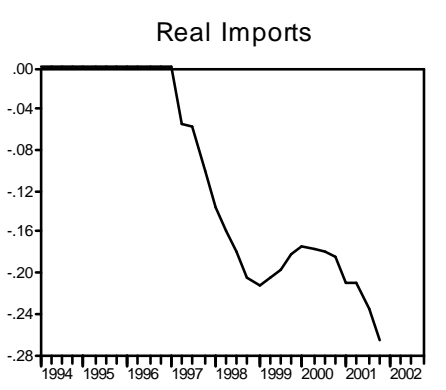

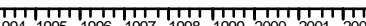

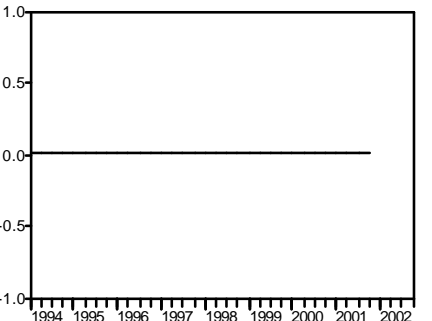


Figure 3

A 1\% Permanent Increase in the Industrial Wages

\section{Percent Deviation}
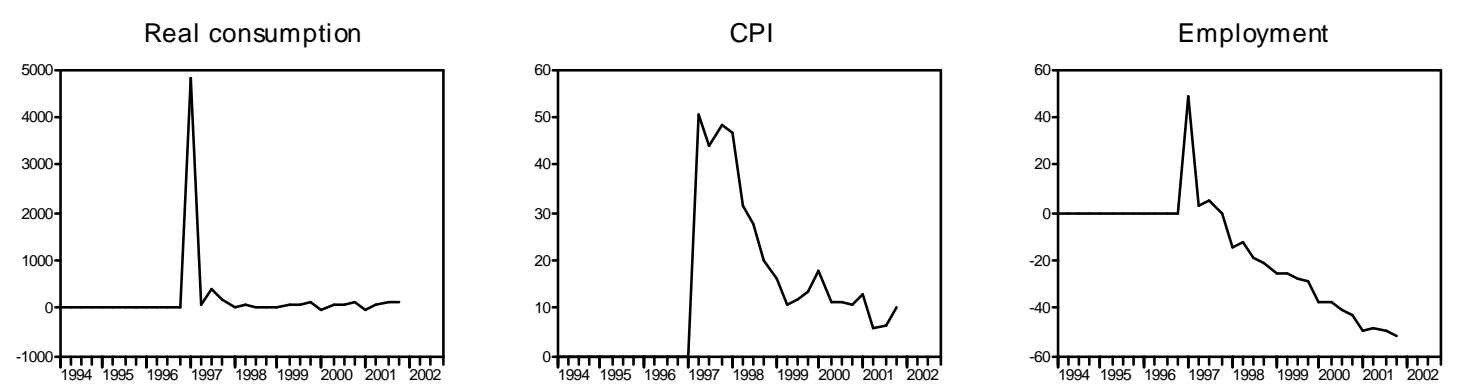

Nominal Exchange Rate

Real Exports

Real Government Expenditures
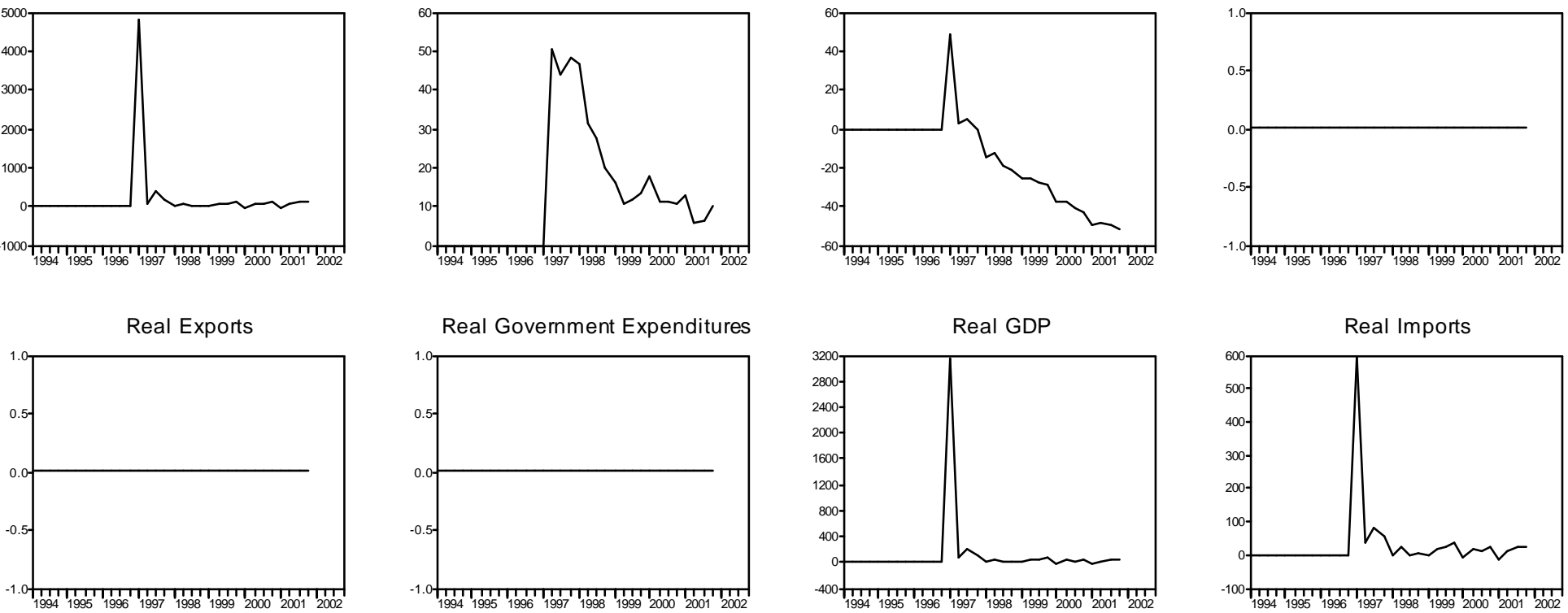

Real Investment

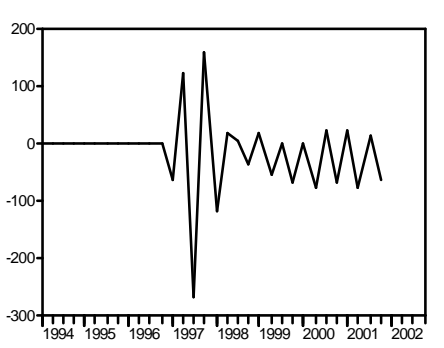

Producer Prices

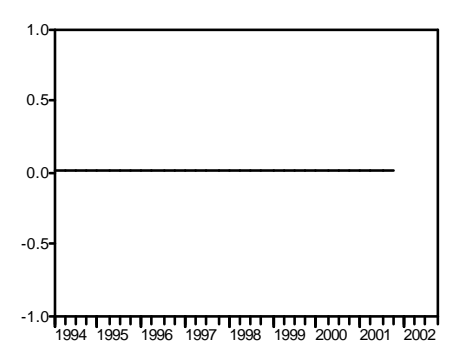

Productivity

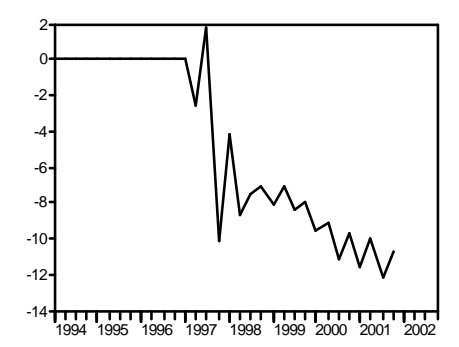

Real Imports

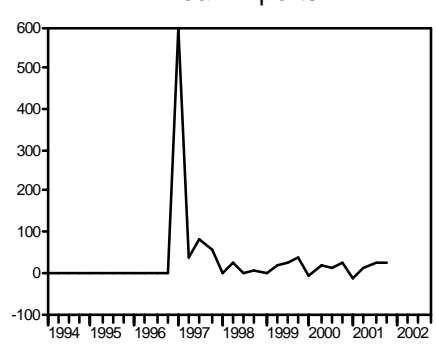

Real Interest Rate
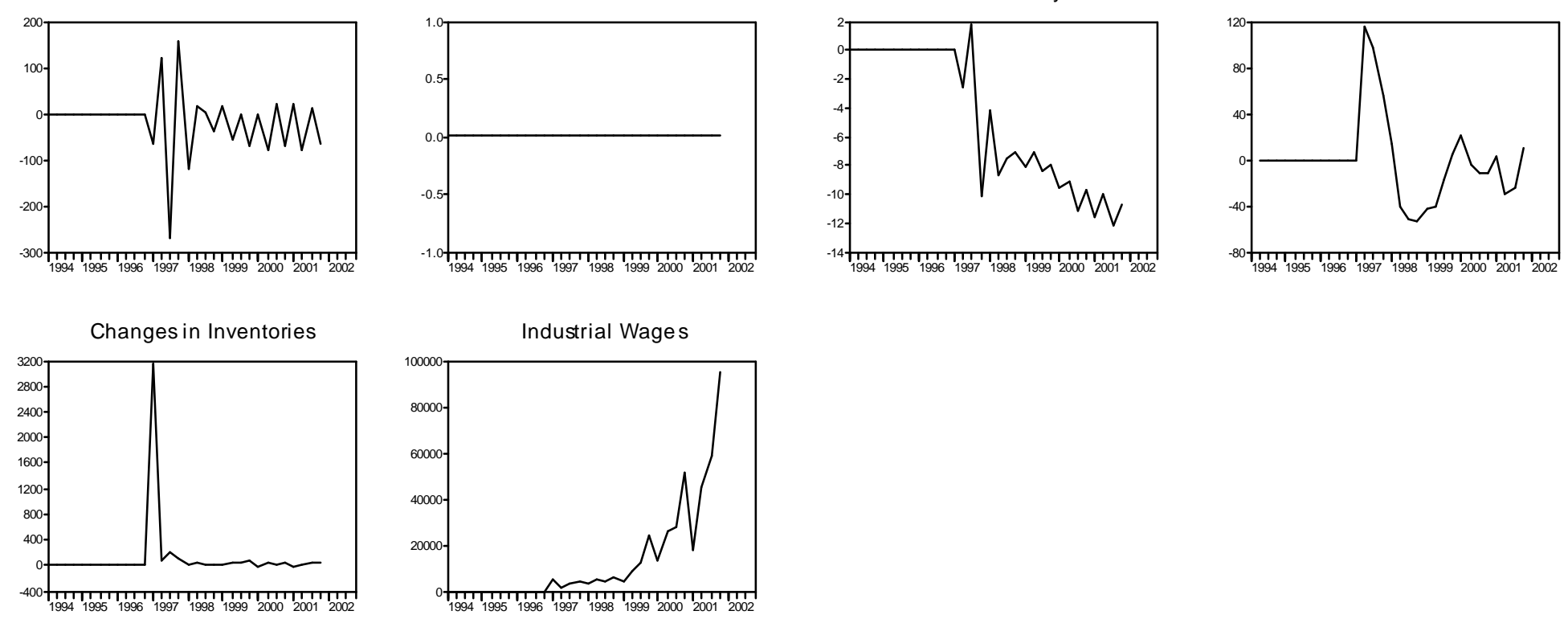
Figure 4

A Permanent Increase in Social Expenditures of $1 \%$ of GDP

\section{Percent Deviation}

Real consumption

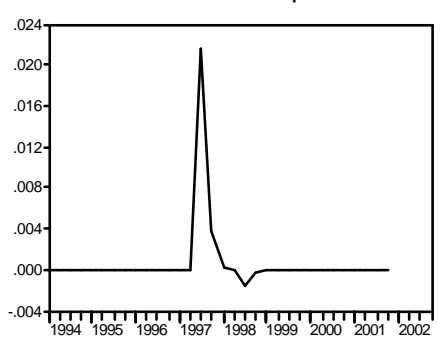

Real Exports

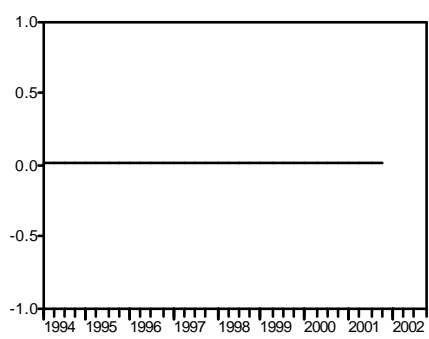

Real Investment

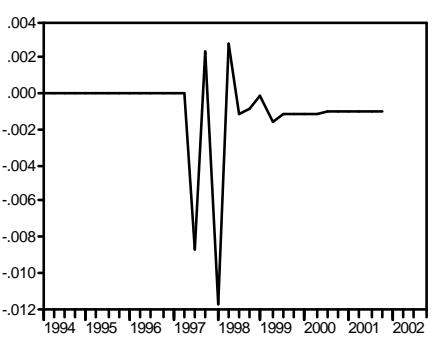

Changes in Inventories

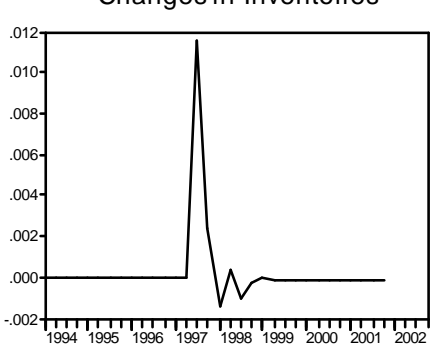

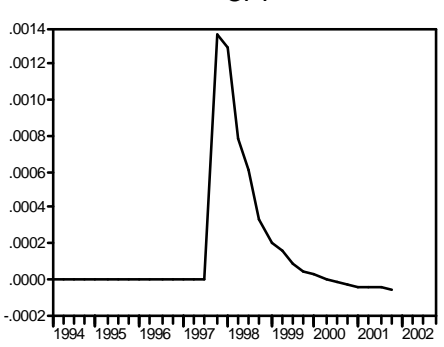

Real Government Expenditures

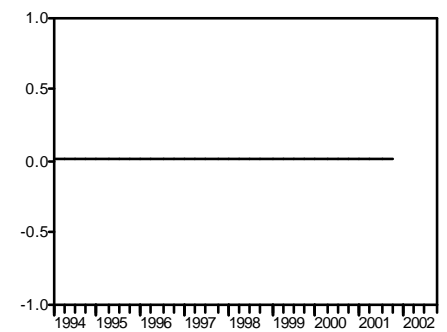

Producer Prices

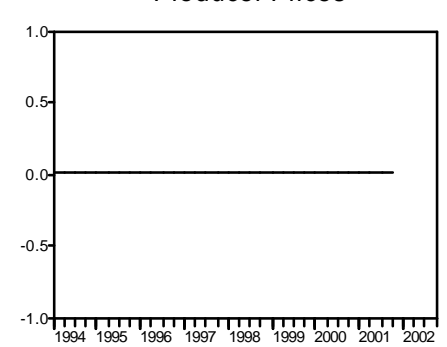

Industrial Wages

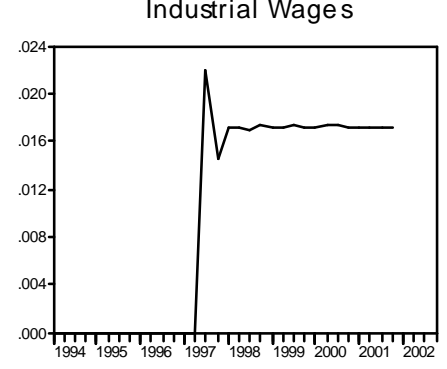

Employment

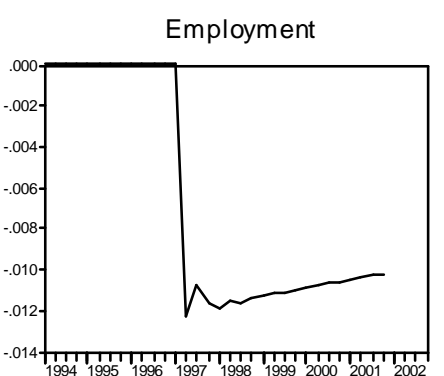

Nominal Exchange Rate

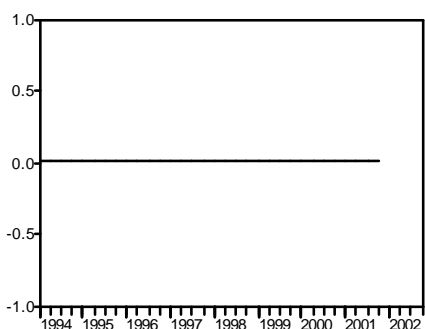

Real Imports

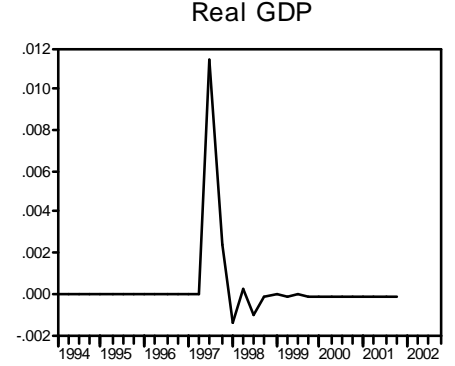

Productivity

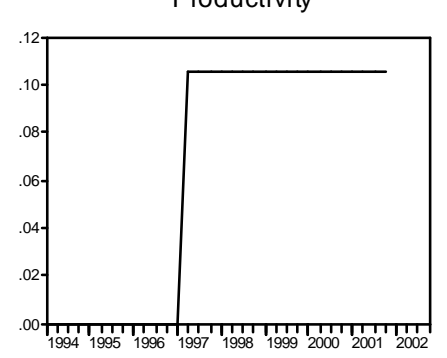

.001

Real Interest Rate

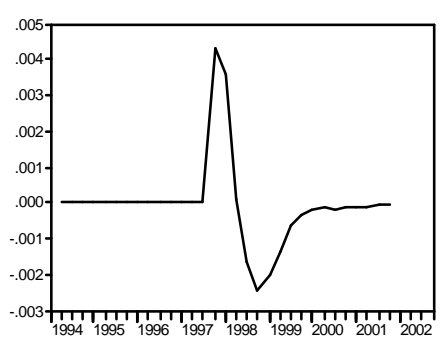




\section{Figure 5}

\section{A 10\% Permanent Increase in US GDP}

\section{Percent Deviation}

Real consumption

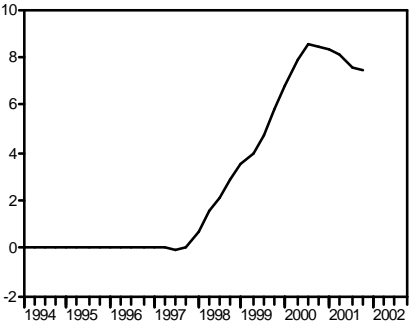

Real Exports

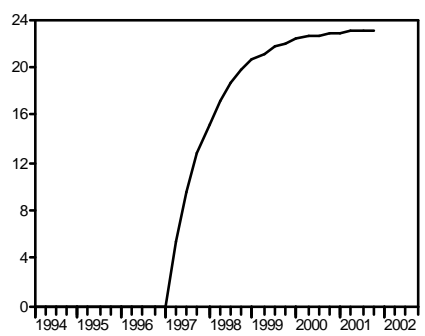

Real Investment

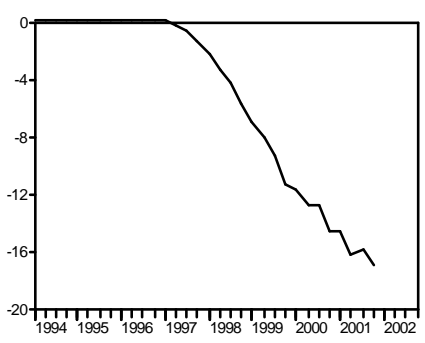

Changes in Inventories

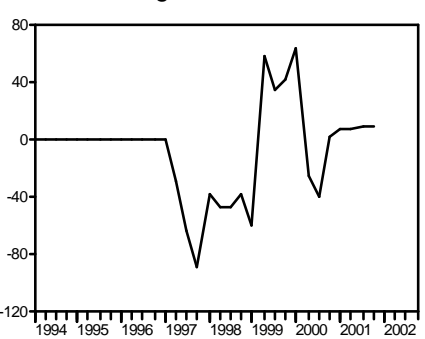

CPI

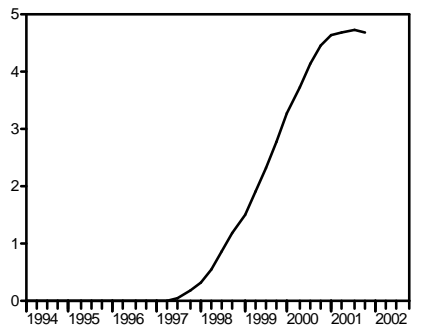

Real Government Expenditures

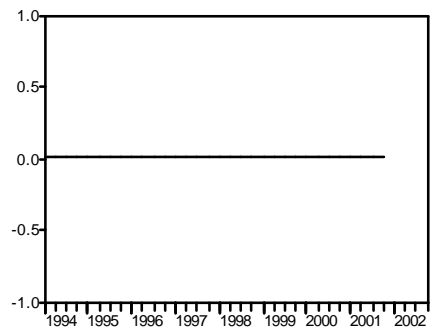

Producer Prices

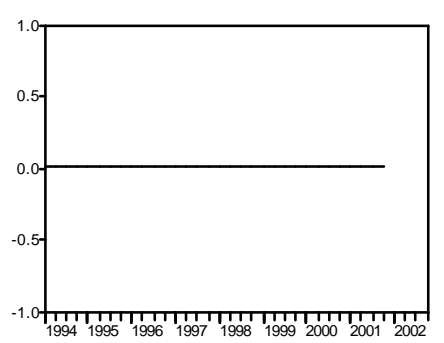

Industrial Wages

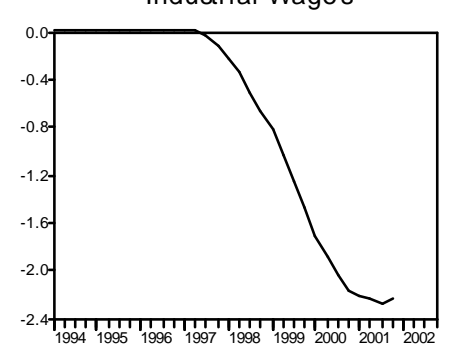

Employment

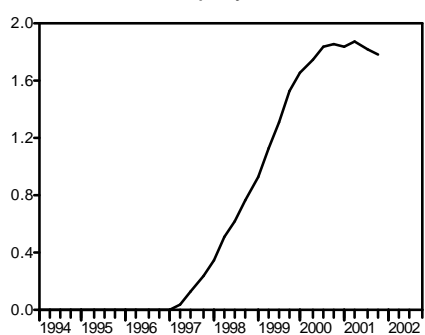

Real GDP

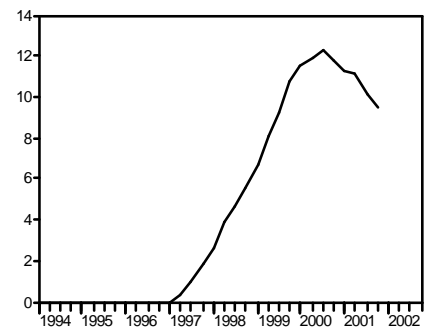

Productivity

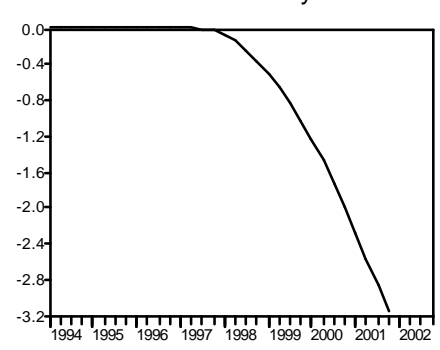

Nominal Exchange Rate

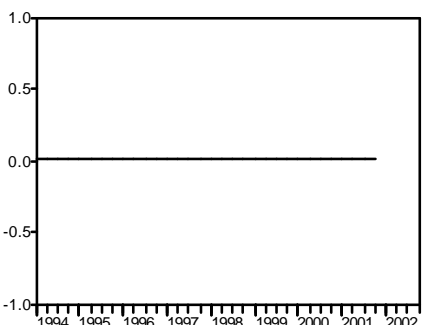

Real Imports

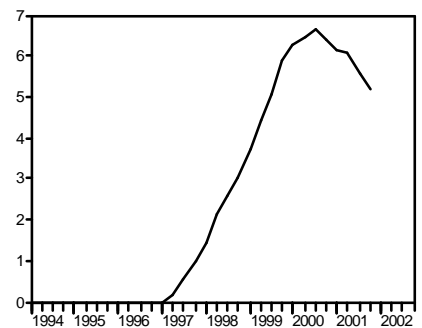

Real Interest Rate

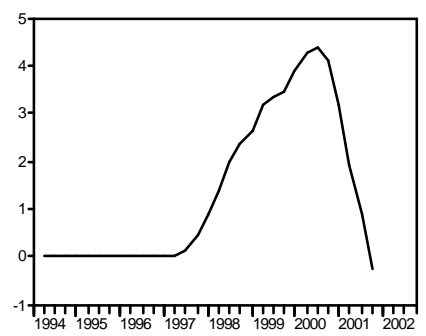


Figure 6

A US $\$ 10$ Permanent Increase in the Crude Oil Prices

Real consumption

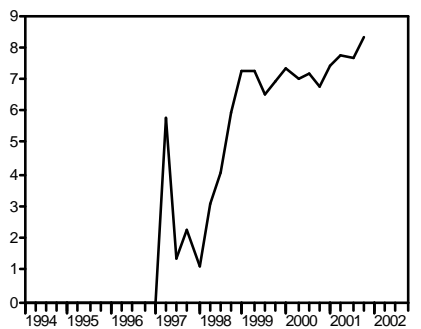

Real Exports

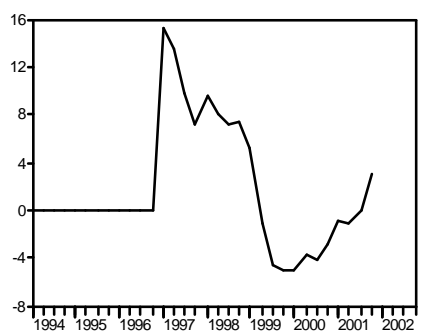

Real Investment

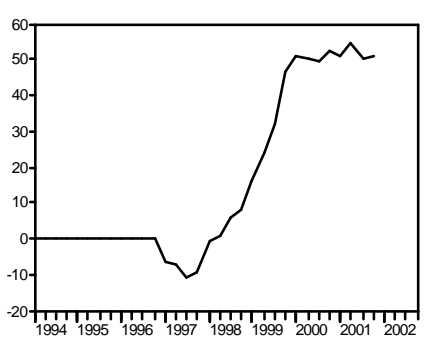

Changes in Inventories

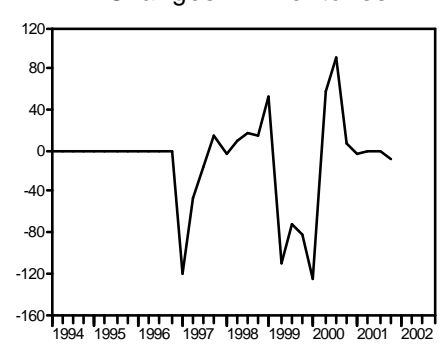

\section{Percent Deviation}

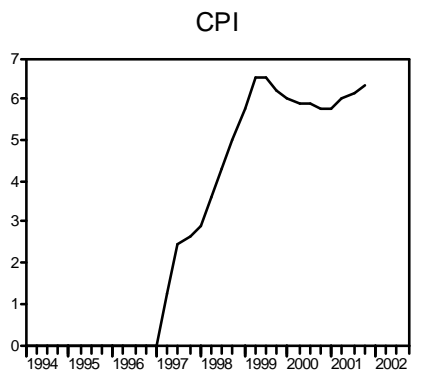

Real Government Expenditures

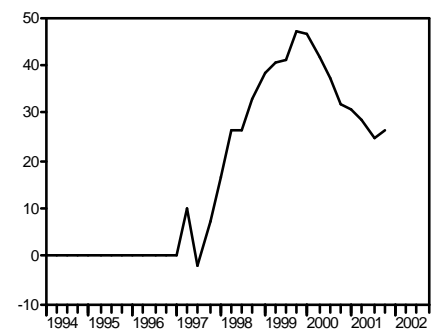

Producer Prices
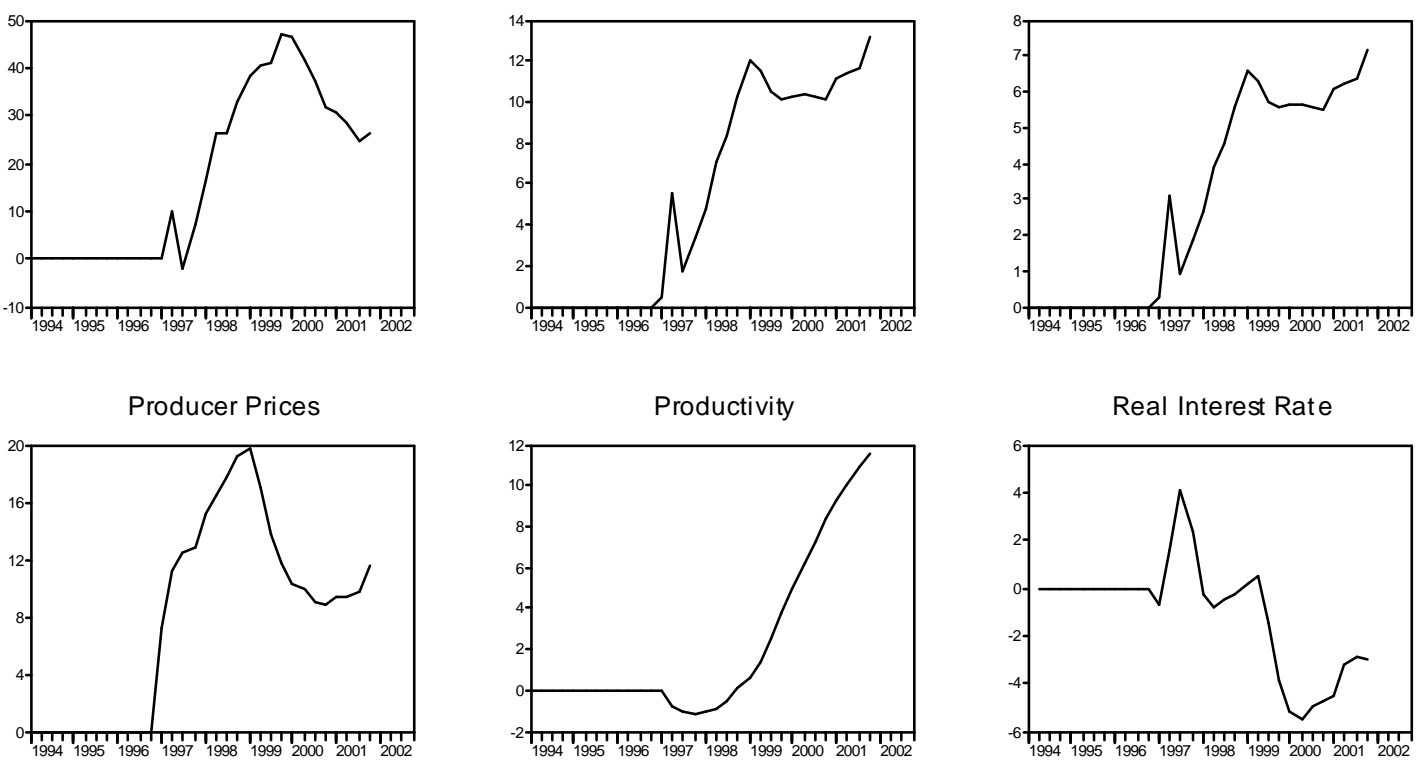

Imports

Real Interest Rate

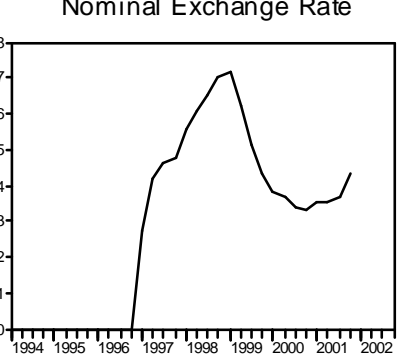

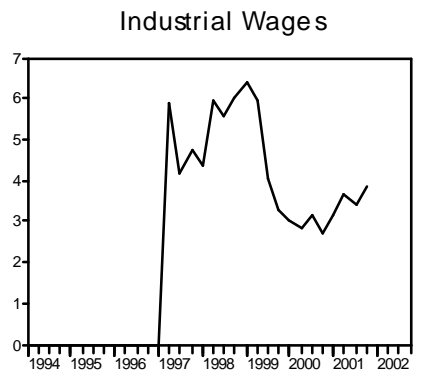

